\title{
Preventing Occupational Corruption: Utilising Situational Crime Prevention Techniques and Theory to Enhance Organisational Resilience
}

\author{
Martin Tunley, Mark Button, David Shepherd and Dean Blackbourn
}

\begin{abstract}
Corruption of all types including occupational corruption causes immense damage to society. Though a number of guides have been published which offer prevention advice, there is very little original criminological research which connects theory to best practice. This paper demonstrates that Clarke's situational crime prevention framework provides a mechanism for operatively analysing specific situations to design and implement prevention methods. The study analyses a variety of techniques, based upon a survey and interviews with counter-corruption professionals, to offers insights into their utilisation and effectiveness. To achieve meaningful implementation of the techniques, countercorruption managers need the delegated power and support of the executive leadership.
\end{abstract}

Keywords: occupational corruption; occupational fraud; bribery; corruption-proofing; situational crime prevention

\section{Introduction}

Corruption is a deeply corrosive economic crime which impacts on governments, public bodies, businesses, charities and citizens across the world. It threatens democracy, damages economies, causes debilitating inefficiencies, diverts funds away from essential public services and exacerbates inequality (Fletcher and Hermann, 2012, p51; Graycar and Sidebottom, 2012). Since the creation of Transparency International (TI) in 1993, corruption has emerged on the world agenda with transnational organisations such as the Organisation for Economic Co-operation and Development (OECD), the United Nations (UN) and the World Bank demanding collective action from national governments, the private sector and civil society. These programmes raise awareness of the problem and appeal to business leaders for voluntary ethical governance reforms whilst seeking more effective law enforcement. The principal target of these initiatives is public corruption (Eicher, 2012, p15), the immoral practices of government officials which support their power, ambitions and bank accounts. Transparency International's definition of corruption has been adopted by many organisations and commentators (United Nations, 2013; Sullivan, 2009; Graycar and Sidebottom, 2012):

\section{"The abuse of entrusted power for private gain."}

TI classifies corruption as political, grand and petty (Transparency International, n.d.). Political corruption is the manipulation of a nation's policies, institutions and resources by political leaders to sustain their power and wealth. Grand corruption is the plundering of state resources by high level politicians and officials. Petty corruption refers to relatively minor abuse by lower level officials in their daily interactions with citizens and small businesses. The OECD is similarly exercised by public corruption but its solutions focus on the supply side (OECD, 2014a, p22). It seeks to dissuade international businesses from paying bribes through more effective national regulations and socially responsible corporate governance. Although corruption may be most visibly egregious, at least through the media, when it involves taxpayers' money, it is not limited to public officials' dealings with suppliers and infrastructure contractors. Commercial (business to business) corruption is a scourge of the private sector, creating inefficiencies, limiting innovation, distorting fair competition and opening opportunities for organised crime and extortion (Sullivan, 2009; Transparency International, 2011). 
The most commonly cited estimates of the scale of corruption are $\$ 1$ trillion paid in bribes annually and a total cost of $\$ 2.6$ trillion or $5 \%$ of global GDP, see for example, Graycar and Prenzler $(2013, p 3)$, Graycar and Sidebottom (2012), OECD (2014b) and Sullivan (2009). It is unfortunate that these figures originate in two public relations publications produced by the World Bank (2004) and the World Economic Forum (2011) with no supporting research evidence. To put these figures into comparative context, the Annual Fraud Indicator (Experian and PKF, 2016) estimates the annual loss to fraud in the UK at $£ 193$ billion, equivalent to $11 \%$ of GDP. The Association of Certified Fraud Examiners estimates that organisations lose $5 \%$ of revenues to occupational fraud and $35 \%$ of schemes involve corruption (ACFE, 2016). A European Commission study estimated that $12.5 \%$ of public procurement contracts are corrupt, and the financial loss to corruption is on average $3.65 \%$ of expenditure (European Commission, 2013). A more recent report by Hafner, Taylor, Disley, Thebes, Barberi, Stepanek and Levi (2016) estimates that the impact of corruption on the GDP of the European Union is between $€ 179 \mathrm{bn}$ and $€ 990 \mathrm{bn}$ in GDP terms ( $1 \%$ to $7 \%$ of GDP). Finally, the PwC (2016) survey of 6,337 companies from 115 countries found that $36 \%$ experienced economic crime in the previous 24 months. It reports that about half of fraudsters are insiders thus implicating ineffective risk assessments of staff roles and weak internal controls.

There are two fundamental problems in estimating the cost of corruption, problems which also impair the effectiveness of regulations and controls. Firstly, corruption is a secret crime (Gorta, 2006). Secondly there is no consensus in its definition (HM Government, 2014; Langseth, 2006). Indeed some researchers, frustrated with lengthy debates, subscribe to the "I know it when I see it" definition (Graycar and Prenzler, 2013, p10; Lambsdorff, 2007; Tanzi, 1998, p564). A significant problem is that corruption is not a unitary phenomenon (Gorta, 2006). It is a taxonomy of overlapping behavioural types, including bribery, fraud, money laundering, theft, embezzlement, electoral fraud, gifts and hospitality, conflict of interest, cronyism, nepotism and lobbying (Langseth, 2006, p11; Transparency International, 2011; Brytting, Minogue and Morino, 2011, p4). These behaviours are subject to interpretation through the variations in laws and cultural norms between countries and regions: behaviour which is socially and legally proscribed in one country may be a perfectly acceptable cultural norm in another (Graycar and Prenzler, 2013, p21; Fletcher and Herrmann, 2012, p16). Social scientists and civil society organisations have a broad view of what constitutes corruption, incorporating legal and unlawful behaviour, for example Petry, Mujica and Vickery (1998). On the other hand, legislators, regulators, lawyers and accountants are concerned with compliance to narrow legal definitions, for example Loughman and Sibery (2012), Brytting, Minogue and Morino (2011) and The Institute of Internal Auditors (2012).

The UK's Bribery Act 2010 prohibits both active (giving) and passive (receiving) bribery by individuals. It applies to public bribery involving domestic and foreign officials, and commercial bribery involving business to business transactions in the UK and overseas. America's Foreign Corrupt Practices Act 15 U.S.C. § 78dd-1 (FCPA) is a federal law which makes both individuals and companies directly liable for the narrow act of actively bribing foreign officials. Domestically, America has federal laws which prohibit active and passive public sector bribery, but it relies on variable state laws for dealing with commercial bribery (Krause and Gibson, 2010). Commercial bribery is completely legal in 13 states. In most of the others, including New York and California, it is permitted provided the recipient's employer consents to the payment (Rohlfsen, 2012). None of the state laws explicitly attach criminal liability to companies. These formulations emphasise the role of the bribe receivers and their breach of trust for a secret gain. Thus it transpires that, even amongst the most advanced economies, bribery in one place is acceptable commercial practice in another; it is contingent on who is involved, who knows about it and where it occurs.

In addition to bribery, examinations of corruption usually incorporate other occupational crimes including employee theft and occupational fraud (Graycar and Smith, 2011, p6) because they share 
characteristics such as abuse of position, breach of trust, secrecy, environmental opportunities, motivations, rationalisations and methods (Brytting, Minogue and Morino, 2011, pxxii). Very often bribery schemes are also purchasing fraud conspiracies: employees award contracts to suppliers who agree to conspire in inflating the value of contracts and pay all or part of the additional sum to the employee (United Nations, 2013, p25; Graycar and Prenzler, 2013, p101). Offenders in these cases are then liable to simultaneous charges of bribery and fraud. The Deputy Property Manager of the Royal Household, Ronald Harper, employed these methods with suppliers to defraud the Crown of $£ 100,000$ (CPS, 2016, August 9). The conspirators in this case disguised and justified the inflated prices by falsifying competitive quotations. The systematic use of this type of scheme by Siemens and other major suppliers in the Iraq Oil-for-Food scandal and elsewhere indicates it is a serious problem (US Department of Justice, 2008).

The literature offers a variety of interlinked causes for corruption based on personality types, individuals' motives and the environmental factors which support or deflect their decisions to offend. Some offenders are just egotistical, wealth and power hungry sociopaths (Brytting, Minogue and Morino, 2011, p89). The majority are ordinary people who do not reflect the traditional image of the criminal (Gabor, 1994, p10). The fraud triangle introduced by Cressey (1953) is frequently offered as the paradigm to explain their corrupt behaviour (Brytting, Minogue and Morino, 2011, p48; United Nations, 2013). Motivational forces include, amongst others, a present financial need, enduring poverty, addictions and the maintenance of status (Gill and Goldstraw-White, 2012, p21-23; Goolsarran, 2006; Albrecht, Sanders, Holland and Albrecht, 2011, p169).

The environmental factors which contribute to the prevalence of corrupt behaviour are also seen as opportunities for combating the problem: the quality of state governance (Tanzi, 1998), the quality of organisations' compliance processes (Schnatterly, 2003) and organisational ethical climate (Schwartz, 2011). There is increasing recognition of the relationship and overlap between the domains in scholarly publications, practitioner texts and practical guides (United Nations, 2010; Independent Commission Against Corruption, 1996). An important environmental factor is the criminogenic nature of corporations born of the profit motive, free market competition and the utilitarian justifications for corrupt practices (Coleman, 1992). Commercial demands can cause employees to behave unethically and sometimes illegally for their employers' benefit, and only indirectly for their own gain (Brytting, Minogue and Morino, 2011, p4). These pressures to breach moral and legal codes increase wherever regulations are opaque and allow discretionary interpretation, and wherever excessive state bureaucracy unnecessarily hinders legitimate enterprise (Tanzi, 1998). Similarly, weak ethical climates which permit excessive workplace pressures, harsh working conditions, discrimination and lack of opportunity can motivate otherwise moral citizens to engage in corrupt practices for their private benefit (Ditton, 1977; Greenberg, 1990; Mars, 1973; Petry, Mujica, and Vickery, 1998).

Because no two organisations are the same, the majority of practice guides, especially those produced by government and civil society organisations, present corruption prevention in terms of generally applicable principles with some supporting advice; the following list is derived from the guides produced by the Ministry of Justice (2011), OECD (2010), United Nations (2011), United States Sentencing Commission (2011):

- Leadership commitment

- Policies, procedures, codes

- Risk assessment

- Training

- Communication

- Whistleblowing

- Monitoring 
- Review

- Disciplinary measures

Sector specific guides adopt these principles to develop menus of predominantly bureaucratic techniques which emphasise particular themes relevant to their target audiences. The Chartered Institute of Public Finance and Accounting's publications focus on the public sector and particular themes are accurate loss measurements and inter-agency co-operation (CIPFA, 2008). The Committee on Standards in Public Life (2015) focuses on the appraisal and monitoring of outsourced public services. The Wegner, Schoberlein and Biermann (2013) guide recommends organisations reward suppliers for good counter-corruption performance and punishes poor practice. The International Chamber of Commerce (2011) provides a long list of bureaucratic control rules for businesses. The Financial Conduct Authority (2015) emphasises third party risks and distorted incentive policies. The texts generally regard structured risk assessments as important anti-corruption tools for both public and private sectors. They assist in identifying the likelihood of threats associated with, for example, external relationships and internal roles, and how these threats may materialise due to weaknesses in operational processes. An important purpose of risk assessments is assisting management to prioritise resources and remedies (United Nations, 2013).

The guidance published tends, however, to lack a basis in quality evidence. A limited amount of research has been undertaken into the prevalence of some of the prevention measures (E\&Y, 2014, 2015, 2016; PwC, 2016; Gee, Button and Cooke, 2010). These survey studies mainly examine the presence of bureaucratic features and activities. The features are artefacts that organisations have, such as policies, contractual rights and whistleblowing hotlines. The activities are things that people do, especially managers, measures such as training and recruitment screening. In all the studies the researchers select a sensibly manageable, but different, combination of tools to quantitatively illustrate counter-corruption performance. There are also important variations in the definitions of the tools: some are thematic, e.g. "internal controls" (E\&Y, 2014), others are specific, e.g. "rights to audit third parties" (E\&Y, 2015). Consequently comparing the survey data is very problematic. Another evident difficulty arises from their basis in subjective perceptions which can lead to incompatible results. In the E\&Y (2015) study $78 \%$ of respondents rated their organisations' ethical standards as good, a result which conflicts with $54 \%$ of senior managers knowing that their organisations falsely reported their financial results. In their later study, E\&Y (2016) found that $39 \%$ of respondents thought corruption was widespread in their country but only $11 \%$ believed it was widespread in their sector: apparently it is always someone else's problem.

There is less research into which techniques work. ACFE (2016) rank the effectiveness of a variety of methods based on their impact on median losses. The least effective tool is external financial audit, producing a $14 \%$ reduction in losses. The top three methods are:

- Pro-active data monitoring/analysis $-54 \%$ reduction

- Management review of processes, accounts and transactions $-50 \%$ reduction

- Hotline $-50 \%$ reduction

In the E\&Y (2014) Middle East survey, the following proportion of respondents stated the methods were effective or very effective:

- Whistleblowing policies $-67 \%$

- Internal controls -64\%

- Internal audit for fraud detection - $62 \%$

- Code of conduct $-61 \%$

- Recruitment screening $-45 \%$ 
The perception by $67 \%$ of participants that whistleblowing policies are effective contrasts with the finding by the same company that whistleblowing facilities are present in only $55 \%$ of organisations $(E \& Y, 2015)$. It is tempting to combine the two results to infer that whistleblowing policies are absent or ineffective in $63 \%$ of organisations. This would be a speculative conclusion, however it demonstrates how survey instruments which do not include presence and effectiveness dimensions can overestimate the impact value of counter-corruption techniques. It also illustrates how a more standardised survey structure would promote measurement concordance between independent research programmes.

Business ethics scholars are concerned with the determinants of the ethical climate, those interactive attributes and characteristics of organisations, leaders and employees which produce consistency in ethical attitudes and behaviour (Trevino and Weaver, 2003). Their enquiries overlap with the bureaucracy based surveys, but are more concerned with employees' perceptions of attitudes and values in organisations, for example, whether senior managers regularly show they care about ethics, whether unethical behaviour is always punished or if efficiency has primacy over ethical considerations (Trevino, Butterfield and McCabe, 1998). Weaver and Trevino (1999) conceptualise two principal idealised types of ethical control systems. The compliance orientated ethical model relies on coercion, rules and regimented control structures to generate conformity rather than moral commitment. The contrasting values orientated ethics programmes appeal to employee aspirations to behave ethically: the notion is that employees are far less likely to even contemplate corrupt behaviour. The guides and surveys introduced above are dominated by the compliance orientated approach. Paine (1996) and Brown, Trevino and Harrison (2005) also allude to a window dressing ethical orientation wherein organisations present ethical features, such as codes and policies, but do not enact what they espouse. This is an important observation which implies that activities are more meaningful than features as survey items because they reflect a real investment in enacting normative values. It also implies that thorough research into counter-corruption techniques should include a dimension which reflects the level of meaningful implementation, a distinct construct from effectiveness because a well implemented technique does not necessarily mean it is an effective technique.

A number of scholars (Benson and Madensen, 2007; Button and Gee, 2013; Gorta, 1998; Graycar and Prenzler, 2013, p71) have proposed using an alternative conceptual framework for the analysis and prevention of occupational corruption: the situational crime prevention theory developed by Clarke $(1995,1997,2008)$. Situational crime prevention has already found application in a range of crimes including terrorism (Clarke and Newman, 2006), sex offending (Wortley and Smallbone, 2006), organised crime (Bullock, Clarke and Tilley, 2010) and e-commerce (Newman and Clarke, 2003). Central to the theory is the idea that crimes are associated with increased opportunities derived from situational factors. The approach is a common sense way of analysing crime settings so that opportunities can be "designed out" with the aim of deflecting would-be offenders and raising the perceived risks of being caught (Clarke, 1995). Clarke (2005) refined his situational crime prevention matrix to 25 techniques under five main methodological types: increasing the effort, increasing the risks, reducing the rewards, reducing provocations and removing excuses. A fundamental premise underpinning the methodology is that it targets rational actors (Clarke and Cornish, 1985). It therefore has limited application to offenders whose psychological and cognitive capabilities are disturbed by, for example, substance abuse or pathological conditions.

There is, however, a dearth of research into its application as an analytical framework and practical approach for addressing corruption. Graycar and Sidebottom (2012) argue that the orthodox approaches, which concentrate on grand initiatives such as regulatory, governance and institutional 
reform, have achieved little in ameliorating corruption. Recognising that opportunity is a key aetiological feature of corruption (see also Cressey, 1953; Gill, 2005; Goldstraw-White, 2011; Schuchter and Levi, 2015), they suggest that adapting the situational crime prevention mentality to corruption should be more fruitful. Their proposition involves analysing the circumstances of real corruption incidents in order to identify control remedies for the "systemic opportunities" (e.g. weak legal regimes) and "localised opportunities" (e.g. inadequate supervision) which attract offenders. This paper seeks to move this discussion forward by examining the usage of a range of corruption prevention techniques through the Clarke (2005) framework. The paper begins by describing the research methodology before introducing the range of techniques organised into the prevention framework. It then presents the findings followed by a brief discussion.

\section{Methodology}

For the purposes of this research, the definition of corruption is the abuse of position for private gain by employees by way of fraud or bribery as defined by the Fraud Act 2006 and the Bribery Act 2010. The paper borrows from Clinard and Quinney $(1973, \mathrm{p} 188)$ to term the errant behaviour as occupational corruption, thereby emphasising the victimhood of the employer and distinguishing it from corporate corruption committed on behalf of the employer. The scope of the research is local, petty, public and commercial sector occupational; it excludes grand and political corruption. Because these types of corruption involve business and political leaders, they are far less likely to be susceptible to the situational prevention approach. The methodology utilised sequential mixed methods data collection, employing an online survey, followed by semi-structured interviews.

The survey focused on the internal environment, the situations which are within the immediate influence and agency control of an organisation's members. The techniques and methods included in the survey were selected for their applicability to organisations in the public, private and charity sectors. Though they are important factors, the survey did not encompass the external environment, including relationships with third parties, where members' agency is diminished and the relationship types differ markedly between the public, private and charity sectors. It also excluded factors relating to values, attitudes, treatment of staff and incentive structures which are more appropriate for employee perception surveys, for example, Trevino, Butterfield and McCabe (1998). The aim of the survey was threefold: to quantify and rank the perceived threat of the most common types of occupational corruption, to assess the usage or level of implementation of 18 techniques, and to gauge the effectiveness of the techniques through the experience of the participants.

Firstly the survey respondents were asked to rate the level of four types of corruption on a scale of 1 to 7 , where 1 is a very small problem and 7 is a very big problem. The four types were 'staff fraud', 'bribery by staff', 'bribery of staff' and 'other integrity problems'.

The methods survey was designed to avoid a simple binary yes or no response to the use of each technique, instead it sought a fuller exploration of the utilisation of each strategy by asking the respondents whether their organisations used the individual methods supporting each technique. The average score ( $\% \mathrm{~lm}$ ' in Table 5) for each group thus represents a rating of meaningful implementation of the technique. A total of 58 methods were included in the survey. These methods are grouped under the 18 techniques in Figure 1. The techniques are in turn arranged under the corresponding strategies within the Clarke (2005) framework. The methods were drawn from the literature introduced above. They were selected because they are not sector specific and because the survey focuses on activities. Only three items represented features: the presence of employee whistleblowing, supplier whistleblowing and a clear set of corruption rules. 
The participants were then asked to rate the effectiveness of each technique on a scale 1 to 7 , where 1 is not very effective and 7 is very effective. The calculated average rating ('Eff' in Table 5) is the best estimate of the effectiveness of each technique based on the experience of the participants.

The survey utilised a convenience sampling method using four mailing lists which included persons holding responsibilities for dealing with occupational corruption:

- $\quad$ Centre for Counter Fraud Studies mailing list;

- $\quad$ Security Institute;

- $\quad$ ASIS UK; and a

- $\quad$ Leading accountancy firm counter fraud contacts list.

As exploratory research, in an area where there has been little research, this was considered the most viable and productive approach. In total 86 usable responses were received. All the usable respondents had professional responsibilities for countering fraud and corruption: security officers, counter-fraud officers, investigators, internal auditors, managers and directors. Although anticorruption compliance is strongly implied in the roles of all the respondents, none described themselves as compliance officers. The 29 overseas respondents were spread across 9 global regions, which meant that, other than the UK, the sample sizes were too small for separate regional analyses. The nature of the sample frame means the findings cannot be generalised. Nevertheless, they do provide an insight into the views and experiences of a wide group of counter corruption professionals regarding the use of preventative tools. As such the findings represent a barometer of experiences that may reflect those of a wider organisational population.

Table 1: Survey sample frame

\begin{tabular}{|l|c|c|c|}
\hline \multicolumn{1}{|c|}{ Sector } & UK & Overseas & Total \\
\hline Public & 36 & 9 & 45 \\
\hline Private & 19 & 17 & 36 \\
\hline Third & 2 & 3 & 5 \\
\hline \multicolumn{1}{|c|}{ Total } & 57 & 29 & 86 \\
\hline
\end{tabular}

In addition to the survey, the research team conducted semi-structured interviews with anticorruption professionals from 12 UK based organisations: four sporting governing bodies, where corruption concerns have galvanised prevention efforts, three large public sector bodies which have experienced occupational corruption, three large private companies, one government regulator and one NGO which has actively sought to encourage and mandate certain strategies for dealing with occupational corruption.

\section{Situational occupational corruption prevention framework}

The prevention framework set out for this study in Figure 1 includes the five strategies developed by Clarke (2005) with the addition of a sixth category, the ethics programme. There is inevitable overlap between the categories, an issue recognised by Wortley(2001) and Cornish and Clarke (2003). This is especially so in the final three categories which are set out to emphasise the overlap.

\section{Increase the effort}

The first strategy in Figure 1 involves deflecting offenders by increasing the required effort to perpetrate corrupt acts (Clarke, 1995). Continuous, visible management controls invoke bureaucratic safeguards and process complexities at transaction events to disrupt offenders' plans. They make it 
more difficult for wrongdoers to carry out their concealed deeds and demands their sustained vigilance to avoid detection, which is why some offenders to not take their annual leave. Physical safeguards and computer vaults protect cash, assets, confidential documents and files. Job rotations disrupt offenders' schemes and corrupt relationships and refresh complacent supervision. Rigorous recruitment screening increases the effort required to gain legitimate access to organisations.

\section{Increase the risks}

The aim of the second strategy is to increase the risks of detection. Offenders innovate methods to circumvent continuous management controls and safeguards. By assessing functional roles for the risks of circumventing controls, organisations can develop situational specific techniques which reinforce safeguards and increase the likelihood of detection and intervention. Discontinuous monitoring and reporting techniques such as surprise audits, staff and system integrity tests, whistleblowing, data analysis and telecoms monitoring, increase detection risks and uncover innovated methods for circumventing existing continuous controls. Although these methods are random, secret activities by design, it is important that they have sufficient publicity and frequency to operate on offenders' risk / reward calculations.

\section{Reduce rewards}

Corrupt employees seek ways to benefit themselves and perhaps others from their crimes. An important strand of situational crime prevention is therefore to find ways of removing or reducing rewards (Clarke and Eck, 2003, p78). Some control methods which increase effort can also reduce rewards. For example, setting contract or expense authority levels may deflect offenders entirely or limit their reward ambitions. Another approach is to stimulate the offender's consciousness of the high consequential costs (Clarke, 1995), including the sanctions indicated in Figure 1, which remove freedoms, deny careers and recover proceeds.

\section{Reduce provocations}

In the context of occupational corruption, the final two categories Clarke advocates, reducing provocations and excuses, are closely linked. These categories could also be viewed as a form of social crime prevention, as they seek to change and support the behaviour and values of the social group and its members. They focus on 'features of the situation that precipitate or induce crime' (Clarke and Eck, 2003, p80), rather than direct opportunity cues. Provocations can arise from the immediate environment, such as exploitative employers (Mars, 1973). They can also be linked to the personal circumstances of an individual outside of the workplace. A person with a drugs, gambling or financial problem, might be a greater risk of committing acts of corruption (Cressey, 1986). Employee assistance programmes, which support individuals with appropriate counselling, dismantle crime rationalisations and reduce offending risks (Nettler, 1974; Giles, 2012, p217; ACFE, 2016). Similarly, structures to support and counsel employees when provoked by ethical dilemmas can neutralise those provocations (Kohlberg and Hersh, 1977). A sales person faced with the toxic blend of pressure to deliver a contract at any cost and a customer demanding a bribe may well need external guidance to decline the temptation.

\section{Remove excuses}

Two key aims of Clarke's fifth strategy are to reduce the permissibility of crimes and to prod consciences (Cornish and Clarke, 2003). This includes clearly setting out, disseminating and reinforcing rules to remove any ambiguities. The strategy is closely linked to reducing provocations in that both strategies are only likely to operate on mundane would-be offenders rather than predatory offenders 
(Cornish and Clarke, 2003). The strategy is also directly associated with dismantling potential rationalising justifications for criminality (Cressey, 1986).

\section{Ethics programme}

The framework proposed by this study introduces a sixth strategy - the ethics programme. The strategy intersects with the other five strategies, especially reducing provocations and excuses. It reflects the central aim of the values orientated climate. It moves beyond the coercive compliance mentality inherent in the first three strategies to engage the ethical role identities of employees in protecting the normative values of the organisation (Weaver and Trevino, 1999). The sample of techniques and methods included in Figure 1 serve to illustrate its relevance to situational corruption prevention. The items selected are restricted to methods which involve disseminating values, learning from events and acquiring understanding of employees' cultural perceptions.

Figure 1: Situational corruption prevention framework

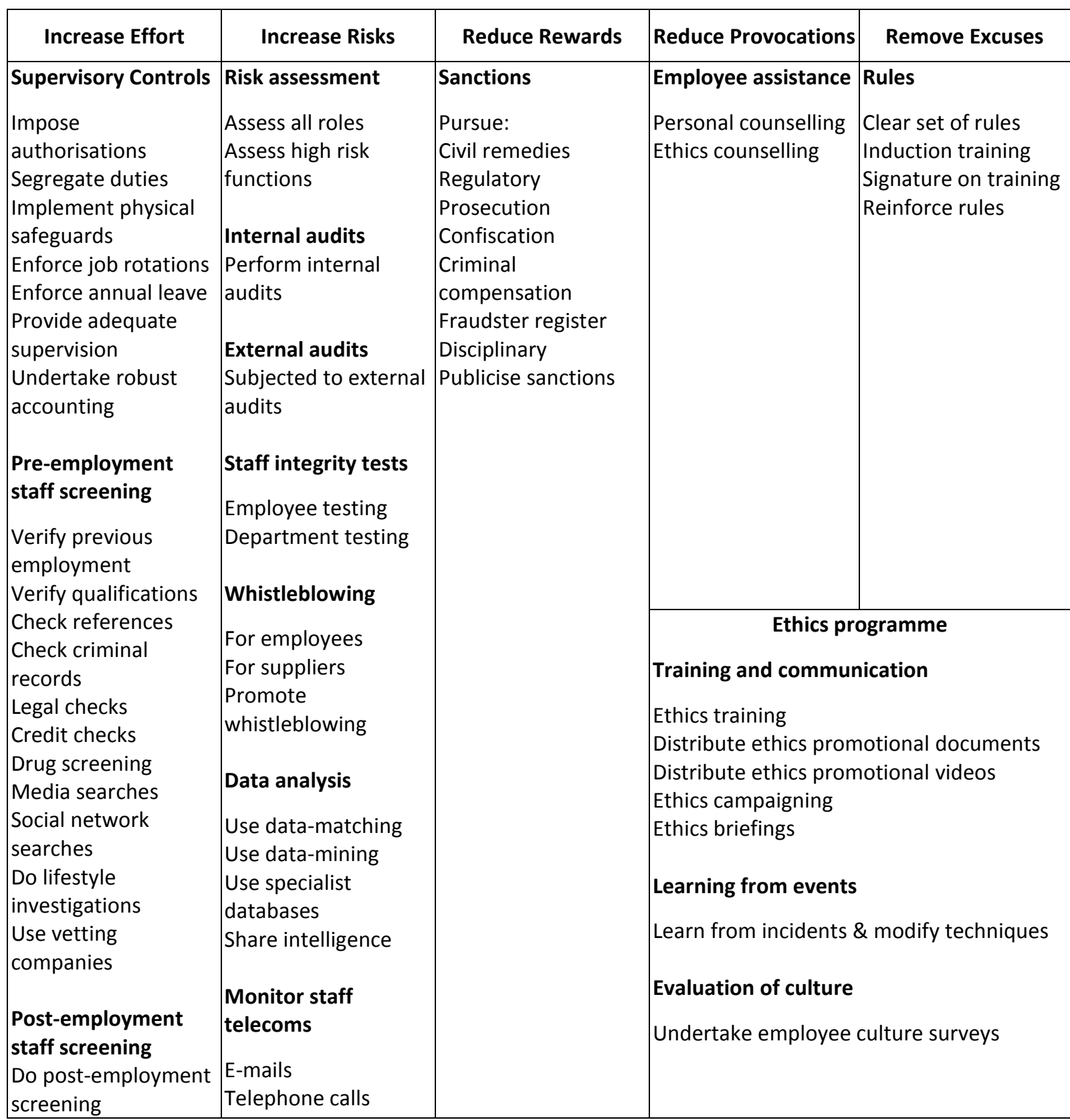




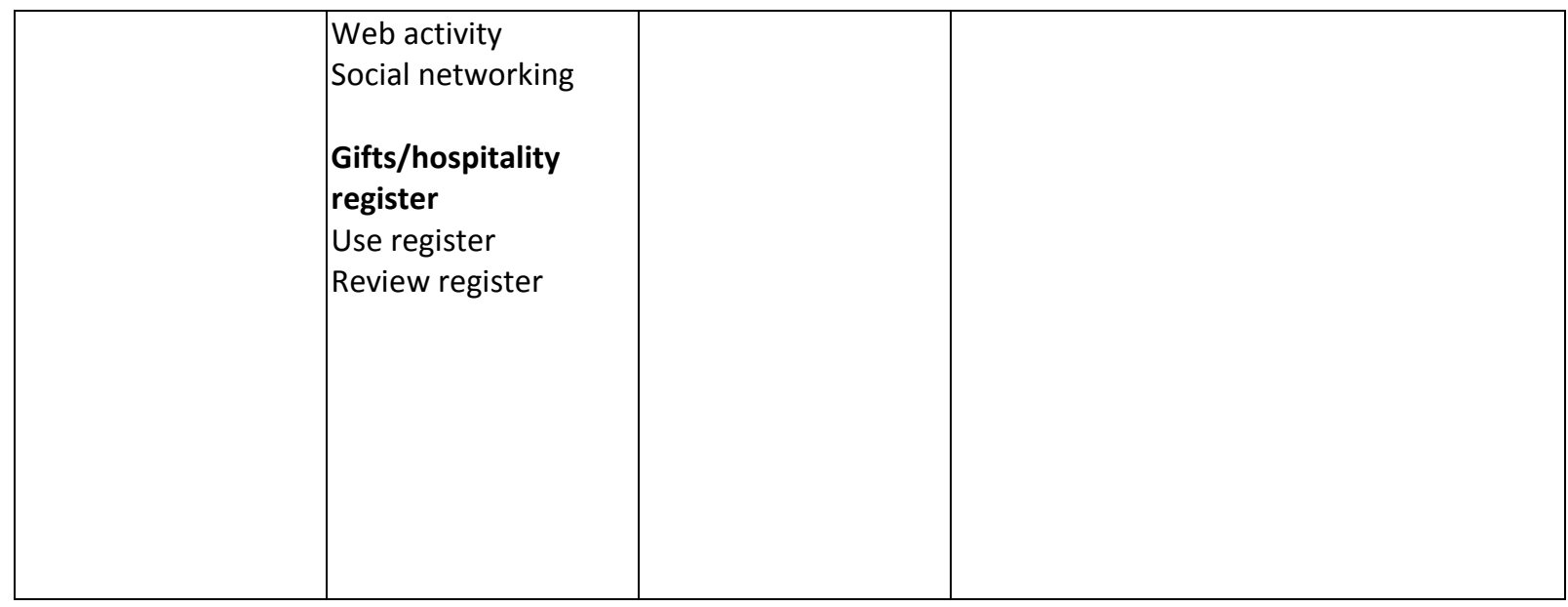

\section{Results}

Scale of corruption

The respondents' views on the scale of corruption is laid out in Table 2 . The data is arranged in three groups: minor (1-2), moderate (3-5) and major problem (6-7). The overall column represents the proportion of respondents indicating a maximum score for any one of the corruption types within the corresponding scale range; for example, $10 \%$ of respondents scored 6 or 7 for at least one of the corruption types.

The results indicate that corruption is a significant problem both in the UK and overseas. Overall 58\% of respondents rate corruption as a significant problem in their organisations, that is, moderate or major for at least one of the types. With an average score of 2.40 , it is a greater problem overseas than in the UK (1.85). 65\% of overseas respondents rate corruption as significant, whilst $55 \%$ view it as a significant in the UK. Employee fraud is clearly the greatest threat both in the UK and overseas with a score of 2.69 and $48 \%$ viewing it as a significant problem. 'Other integrity problems' is the second highest category with an average score of 2.56 , which exceeds both the active and passive forms of bribery. This is an unexpected result. The constraints on the survey did not allow collecting data on what these unspecified issues might be and warrants further investigation.

Table 2: Perceptions of the scale of corruption - UK and overseas

\begin{tabular}{|c|c|c|c|c|c|c|c|}
\hline & Scale & $\begin{array}{c}\text { Scale } \\
\text { descriptor }\end{array}$ & Staff Fraud & $\begin{array}{c}\text { Bribery by } \\
\text { staff }\end{array}$ & $\begin{array}{c}\text { Bribery of } \\
\text { staff }\end{array}$ & $\begin{array}{c}\text { Other } \\
\text { integrity } \\
\text { problems }\end{array}$ & Overall \\
\hline \multirow{4}{*}{ All regions } & $1-2$ & Minor & $52 \%$ & $90 \%$ & $80 \%$ & $73 \%$ & $42 \%$ \\
\hline & $3-5$ & Moderate & $41 \%$ & $10 \%$ & $19 \%$ & $24 \%$ & $48 \%$ \\
\hline & $6-7$ & Major & $7 \%$ & $0 \%$ & $1 \%$ & $4 \%$ & $10 \%$ \\
\hline & \multicolumn{2}{|c|}{ Average score } & 2.69 & 1.49 & 1.83 & 2.10 & 2.03 \\
\hline \multirow{4}{*}{ UK } & $1-2$ & Minor & $56 \%$ & $98 \%$ & $89 \%$ & $79 \%$ & $46 \%$ \\
\hline & $3-5$ & Moderate & $35 \%$ & $2 \%$ & $11 \%$ & $19 \%$ & $44 \%$ \\
\hline & $6-7$ & Major & $9 \%$ & $0 \%$ & $0 \%$ & $2 \%$ & $11 \%$ \\
\hline & \multicolumn{2}{|c|}{ Average score } & 2.68 & 1.23 & 1.57 & 1.88 & 1.85 \\
\hline Overseas & $1-2$ & Minor & $45 \%$ & $75 \%$ & $61 \%$ & $59 \%$ & $34 \%$ \\
\hline
\end{tabular}




\begin{tabular}{|r|r|l|r|r|r|r|r|}
\hline & $3-5$ & Moderate & $52 \%$ & $25 \%$ & $36 \%$ & $33 \%$ & $55 \%$ \\
\cline { 2 - 7 } & $6-7$ & Major & $3 \%$ & $0 \%$ & $4 \%$ & $7 \%$ & $10 \%$ \\
\cline { 2 - 7 } & \multicolumn{2}{|c|}{ Average score } & 2.69 & 2.00 & 2.36 & 2.56 & 2.40 \\
\hline
\end{tabular}

Tables 3 and 4 provide a more detailed breakdown by geography and sector, ranked by score and prevalence. It should be noted that the third sector data is included in the overall results for each region, but the sample size $(n=5)$ is too small for a separate analysis. The overall percentage figures in Table 4 represent the proportion of respondents in each sector who rated one or more types of corruption as significant in their organisations. The majority of respondents assess corruption of at least one type as significant in all sectors except the private sector in the UK (42\%). The data also suggests that the public sector is more prone to corruption both in the UK $(61 \%)$ and overseas $(67 \%)$. The view that passive bribery of staff is more prevalent than active bribery by employees is consistent across all the sectors. This is to be expected in the public sector where there is less utilitarian purpose in offering bribes. However, because bribery involves two parties, the prevalence of active and passive bribery in the private sector should in reality converge. The difference may be due to sampling error. Alternatively it may arise from a perception bias formed of a view that active bribery is morally more heinous than passive bribery.

Table 3: Average scores by type and sector

\begin{tabular}{|l|r|r|r|r|r|r|r|r|r|}
\cline { 2 - 11 } \multicolumn{1}{c|}{} & \multicolumn{3}{c|}{ UK and overseas } & \multicolumn{3}{c|}{ Overseas } & \multicolumn{3}{c|}{ UK } \\
\hline Corruption type & $\begin{array}{c}\text { All } \\
\text { sectors }\end{array}$ & Private & Public & $\begin{array}{c}\text { All } \\
\text { sectors }\end{array}$ & Private & Public & $\begin{array}{c}\text { All } \\
\text { sectors }\end{array}$ & Private & Public \\
\hline Staff fraud & 2.69 & 2.58 & 2.71 & 2.69 & 2.76 & 2.22 & 2.68 & 2.42 & 2.83 \\
\hline Other & 2.10 & 2.08 & 2.11 & 2.56 & 2.53 & 2.63 & 1.88 & 1.68 & 2.00 \\
\hline Bribery of staff & 1.83 & 2.06 & 1.64 & 2.36 & 2.65 & 1.67 & 1.57 & 1.50 & 1.64 \\
\hline Bribery by staff & 1.49 & 1.63 & 1.30 & 2.00 & 2.18 & 1.25 & 1.23 & 1.11 & 1.31 \\
\hline \multicolumn{1}{|c|}{ Overall } & 2.03 & 2.09 & 1.94 & 2.40 & 2.53 & 1.94 & 1.85 & 1.69 & 1.94 \\
\hline
\end{tabular}

Table 4: Perceived prevalence of significant (moderate to major) corruption

\begin{tabular}{|l|r|r|r|r|r|r|r|r|r|}
\cline { 2 - 10 } \multicolumn{1}{c|}{} & \multicolumn{3}{c|}{ UK and overseas } & \multicolumn{3}{c|}{ Overseas } & \multicolumn{3}{c|}{ UK } \\
\hline Corruption type & $\begin{array}{c}\text { All } \\
\text { sectors }\end{array}$ & Private & Public & $\begin{array}{c}\text { All } \\
\text { sectors }\end{array}$ & Private & Public & $\begin{array}{c}\text { All } \\
\text { sectors }\end{array}$ & Private & Public \\
\hline Staff fraud & $48 \%$ & $42 \%$ & $49 \%$ & $55 \%$ & $53 \%$ & $44 \%$ & $44 \%$ & $32 \%$ & $50 \%$ \\
\hline Other & $27 \%$ & $25 \%$ & $30 \%$ & $41 \%$ & $35 \%$ & $50 \%$ & $21 \%$ & $16 \%$ & $25 \%$ \\
\hline Bribery of staff & $20 \%$ & $31 \%$ & $11 \%$ & $39 \%$ & $47 \%$ & $22 \%$ & $11 \%$ & $17 \%$ & $8 \%$ \\
\hline Bribery by staff & $10 \%$ & $14 \%$ & $2 \%$ & $25 \%$ & $29 \%$ & $0 \%$ & $2 \%$ & $0 \%$ & $3 \%$ \\
\hline \multicolumn{1}{|c|}{ Overall } & $58 \%$ & $50 \%$ & $62 \%$ & $66 \%$ & $59 \%$ & $67 \%$ & $54 \%$ & $42 \%$ & $61 \%$ \\
\hline
\end{tabular}

\section{Counter-corruption techniques}

The following sections introduce the results of the methods survey, organised by strategy categories. Increase effort 
The three techniques classified under increasing the effort are ranked in order of effectiveness in Table 5.

Table 5: Increase the effort

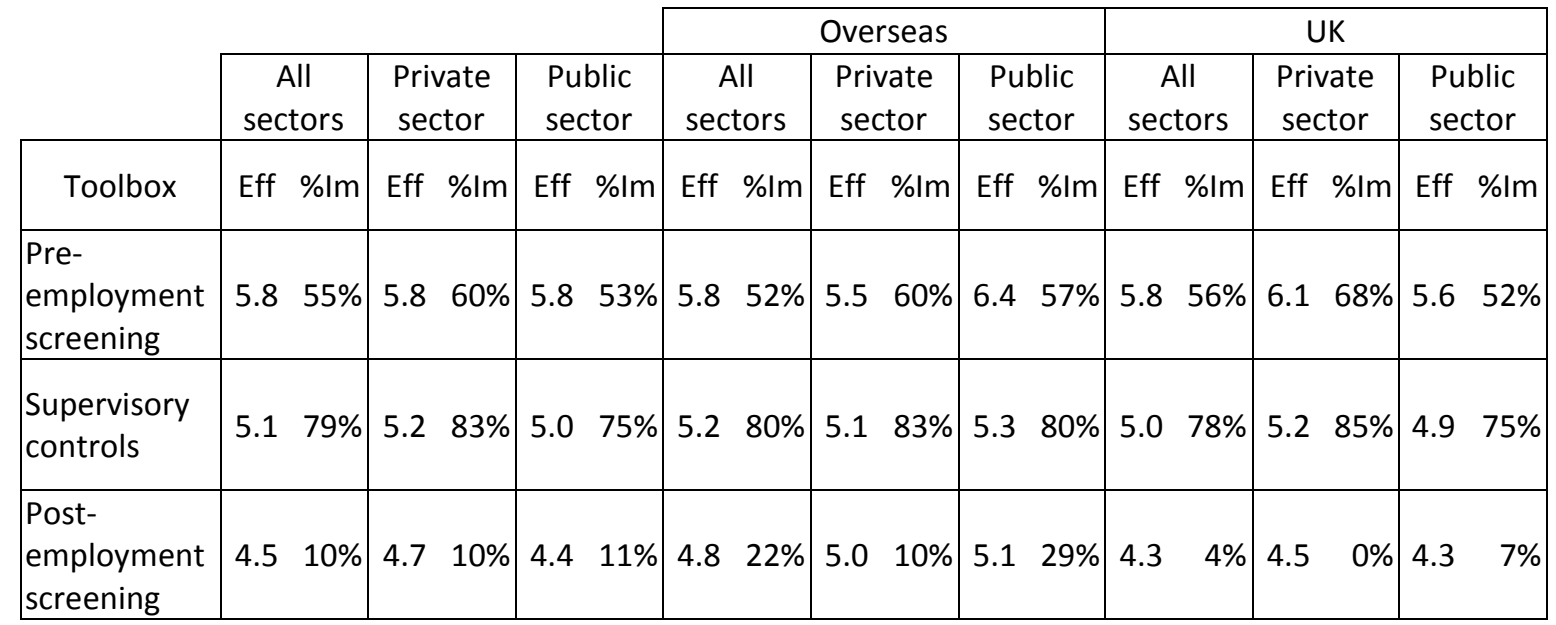

Recruitment screening is regarded as the most effective tool in all sectors, but the $55 \%$ implementation level indicates that many organisations are not using the full range of tools. Whilst the majority of organisations do the simple things with $90 \%$ verifying previous employment and $89 \%$ taking up references, it is concerning that $10 \%$ do not and only $79 \%$ check qualifications. Just $30 \%$ undertake credit checks and only $24 \%$ perform media and social media searches. One interviewee illustrated the importance of adequate recruitment due diligence:

"We have introduced some areas to the HR team to consider when recruiting, because .... it's certainly on the rise, whether it's actually on the rise or whether or not it's on people's radar now, but several people have been caught with falsified qualifications." (Senior Fraud Manager, public sector)

A common theme arising from the interviews is that organisations routinely perform the "normal assessments", verifying previous employment, references and qualifications, but only undertake the additional measures in support of investigations. Even checking qualifications is too often overlooked. The recruitment screening process of one company is dominated by criminal record checks, driven by its involvement in the defence industry. The other checks, including verifying qualifications, were rarely undertaken due to irresponsible parochialism and discordance between departments:

"I would [do those checks], but it's an HR function and HR and ourselves disagreed with what their roles were." (Security Manager, private sector)

Post-employment screening is a valuable tool, at least for higher risk roles, because the life circumstances of individuals can change for the worse, causing strains and provocations (Clarke, 2005). It is also of value when organisations consider transferring or promoting individuals into positions of higher sensitivity, power and spending authority. However it is regarded as the least effective of the three techniques and is used infrequently. A private sector interviewee was quite clear: "No, we never do that, only if there is a cause to do an investigation." Again, it is apparent that some of the methods are used reactively to support investigations rather than for prevention purposes. One participant uses a register of declared interests to assist their post-employment screening and checks the veracity of the register against social media sources and Companies House listings to detect purchasing fraudsters: 
"Because again, the occasional fraud we get turning up is, you know, people with undeclared interests, their own companies, you know, putting contracts out through these companies." (Senior Counter Fraud Specialist, public sector)

The implementation of supervisory controls is by far the highest of the increasing the effort techniques at $79 \%$ overall. Within this group setting appropriate authority levels $(97 \%)$ and ensuring physical safeguards (96\%) is relatively high, but adequate accounting systems (92\%), segregation of duties (89\%), supervisory capacity (74\%) and enforcing annual leave (74\%) are surprisingly low. The least used technique is ensuring job rotation (25\%). For the gaming industry high frequency job rotation is essential in preventing the development of corrupt relationships:

"There's constant changing of the dealers, which is another way of chopping and changing and making sure there's a break up. So one of the things managers are asked to look for is customers that come in and specifically request one specific dealer or only go and play when one dealer's playing on a table." (Security Director, regulator)

\section{$\underline{\text { Increase risks }}$}

The nine techniques for increasing risk are listed in order of effectiveness in Table 6. Braithwaite (1989) suggested that organisations full of ethical antennae are inhospitable environments for occupational crime. The survey respondents agree, rating whistleblowing as the most effective techniques for the risks to offenders. One interviewee said of whistleblowing:

"I think you can't do without it. I think you'd be foolish otherwise because it is something quite simple to manage." (Head of Anti Bribery and Corruption, private sector)

An interviewee from the healthcare sector has a high regard for whistleblowing systems: they work "very, very well" in relation to financial fraud and to professional competency problems. $90 \%$ of the participating organisations have employee whistleblowing systems. However their level of implementation and consequent impact is reduced to $78 \%$ because only $77 \%$ of the organisations extend the systems to their suppliers and only $67 \%$ promote the systems. Having a secret, dormant system is meaningless, it needs to be promoted and encompass all relevant stakeholders.

Table 6: Increase the risks

\begin{tabular}{|c|c|c|c|c|c|c|c|c|c|c|c|c|}
\hline \multirow[b]{3}{*}{ Toolbox } & & & & & & \multicolumn{3}{|c|}{ Overseas } & \multicolumn{4}{|c|}{ UK } \\
\hline & $\begin{array}{c}\text { All } \\
\text { sectors }\end{array}$ & \multicolumn{2}{|c|}{$\begin{array}{l}\text { Private } \\
\text { sector }\end{array}$} & \multicolumn{2}{|c|}{$\begin{array}{l}\text { Public } \\
\text { sector }\end{array}$} & $\begin{array}{c}\text { All } \\
\text { sectors }\end{array}$ & $\begin{array}{c}\text { Private } \\
\text { sector }\end{array}$ & $\begin{array}{l}\text { Public } \\
\text { sector }\end{array}$ & $\begin{array}{c}\text { All } \\
\text { sectors }\end{array}$ & $\begin{array}{l}\text { Private } \\
\text { sector }\end{array}$ & \multicolumn{2}{|c|}{$\begin{array}{l}\text { Public } \\
\text { sector }\end{array}$} \\
\hline & $\% \mathrm{Im}$ & Eff & $\% \operatorname{lm}$ & Eff & $\% \operatorname{lm}$ & Eff \% Im & Eff $\%$ Im & Eff \%Im & Eff $\% \mathrm{Im}$ & Eff $\%$ Im & Eff & $\% \mathrm{Im}$ \\
\hline Whistleblowing & $5.178 \%$ & 5.3 & $73 \%$ & 4.9 & $84 \%$ & $5.277 \%$ & $4.073 \%$ & $5.6 \quad 71 \%$ & $5.179 \%$ & $5.867 \%$ & 4.8 & $87 \%$ \\
\hline Data analysis & $5.045 \%$ & 5.0 & $38 \%$ & 4.9 & $50 \%$ & $4.737 \%$ & $5.238 \%$ & $4.0 \quad 32 \%$ & $5.148 \%$ & $4.936 \%$ & 5.1 & $54 \%$ \\
\hline $\begin{array}{l}\text { Gifts/hospitality } \\
\text { register }\end{array}$ & $4.676 \%$ & 4.9 & $84 \%$ & 4.5 & $72 \%$ & $4.274 \%$ & $3.984 \%$ & $5.164 \%$ & $4.876 \%$ & $5.686 \%$ & 4.4 & $74 \%$ \\
\hline $\begin{array}{l}\text { Web/telecoms } \\
\text { monitoring }\end{array}$ & $4.348 \%$ & 4.5 & $52 \%$ & 4.3 & $45 \%$ & $4.061 \%$ & $3.952 \%$ & $4.368 \%$ & $4.5 \quad 42 \%$ & $4.934 \%$ & 4.3 & $40 \%$ \\
\hline Internal audit & $4.366 \%$ & 4.4 & $69 \%$ & 4.1 & $64 \%$ & $4.663 \%$ & $4.269 \%$ & $5.171 \%$ & $4.267 \%$ & $4.775 \%$ & 3.9 & $63 \%$ \\
\hline
\end{tabular}




\begin{tabular}{|l|ll|ll|ll|ll|ll|ll|ll|ll|ll|}
\hline System tests & 4.3 & $13 \%$ & 4.1 & $14 \%$ & 4.2 & $14 \%$ & 4.5 & $23 \%$ & 4.0 & $14 \%$ & 4.7 & $29 \%$ & 4.2 & $8 \%$ & 4.2 & $6 \%$ & 4.1 & $10 \%$ \\
\hline Integrity tests & 4.0 & $12 \%$ & 3.6 & $11 \%$ & 4.4 & $14 \%$ & 4.0 & $20 \%$ & 3.3 & $11 \%$ & 5.3 & $43 \%$ & 4.0 & $8 \%$ & 3.7 & $9 \%$ & 4.1 & $8 \%$ \\
\hline Risk assess roles & 4.0 & $40 \%$ & 4.5 & $49 \%$ & 3.7 & $33 \%$ & 4.1 & $47 \%$ & 4.0 & $49 \%$ & 4.7 & $53 \%$ & 4.0 & $36 \%$ & 5.0 & $51 \%$ & 3.5 & $29 \%$ \\
\hline External audit & 3.6 & $98 \%$ & 3.8 & $94 \%$ & 3.5 & $100 \%$ & 3.9 & $97 \%$ & 3.5 & $69 \%$ & 4.7 & $71 \%$ & 3.5 & $98 \%$ & 4.0 & $89 \%$ & 3.2 & $100 \%$ \\
\hline
\end{tabular}

Data analysis using data mining, data matching, the use of fraudster databases and intelligence sharing is also regarded as an effective strategy (rated 5.0), but its implementation is poor (45\%). An interviewed system provider finds that many organisations are unwilling to invest in the technique because they cannot quantify the benefits, yet he is convinced the payback is swift:

"The method is effective at looking at payroll records and expenses. It data matches, for example, timings and locations. So you might expect the card to be used whilst an official is away on business at 10:00 in the evening, but you wouldn't expect it to be used at 10:00 in the morning on a Saturday in Asda....We introduced the system to look at procurement cards in the Met some years ago but, before it went live, the management decided to [delay] and announced an amnesty. They gave their people 3 months to voluntarily pay back money before it went live. They got back $£ 250,000$ in 3 months." (Senior Counter Fraud Specialist, private sector)

Third in the effectiveness rating at 4.6 is the gifts and hospitality register. The technique has multiple impacts on offenders: it increases risk, removes excuses by laying out rules, alerts people's conscience and reduces rewards. $97 \%$ of participants operate a register, but only $54 \%$ check its veracity. As one government employee pointed out, the register is only truly useful if it is regularly assessed to detect employees' dishonesty:

"We created an electronic version and made it very clear that if people fail to make an entry we could take disciplinary action if they make an entry knowingly false. For example it's not unusual for people to try and get something nice such as tickets to a football match, tell us its worth $£ 10$, you do a check see its worth $£ 50$. So whereas we'd give some leeway, you wouldn't give that sort of leeway and we have lost people because I would consider that to be a false statement, so it's unacceptable." (Counter Fraud Manager, public sector)

System and integrity tests are rarely employed for prevention purposes, but interviewees reported they are occasionally used to assist investigations. The most puzzling result is the relatively low regard afforded to risk assessment of employee roles (4.0) and its lack of use (40\%). A regulator participant extolled the value of risk assessments:

"I mean I think it's fundamental, certainly in the private sector, to understanding what are the corruption risks you're facing and I have little confidence that you can build a good anti-corruption system or procedure unless you've got a good risk assessment because you don't really know the challenge you're trying to address." (Security Director, regulator)

Further research is required to explain the survey outcome because risk assessment is an important component of effective counter-fraud strategies (Brooks, Button and Frimpong, 2009) and it is an essential component of a general anti-corruption system (BS 10500:2011). However the inference that 
can be drawn from the statement of one Security Manager reflects the Braithwaite and Fisse (1987, p226) assertion that the counter-corruption function needs clout:

"We force Commercial, Finance, HR, whoever it is [to do risk assessments]. We've made it a standing agenda item on our meetings. We do a full review every six months, which then feeds into the audit team and actions back to the departments." (Security Manager, private sector)

Finally it is worth noting that the technique most often implemented is the external audit (98\%), but it is the least effective in countering corruption (3.6). The explanation for this apparent paradox is probably that external audits are a regulatory obligation for large organisations, but their purpose is to determine whether the organisations accounts are fair, it is not to find corruption.

\section{$\underline{\text { Reduce rewards }}$}

The premise behind Clarke's third strategy is that the rational actor is able to adequately quantify the benefits of his planned actions. Benefits must at least be broadly anticipated for this strategy to have any purpose. There are a number of methods which have a secondary effect of reducing rewards, for example setting authorisation levels and hospitality registers. Clarke's framework does not include formal sanctions or their effects. However they do have consequential costs (Clarke, 1995; Wegner, Schoberlein and Biermann, 2013, p33) which operate on the rational choice decisions of potential offenders in calculating the anticipated net rewards, however broadly imagined by the rational actor, after deducting the direct and associated costs of sanctions (Clarke and Cornish, 1985): criminal, regulatory sanctions, loss of career, stigmatisation, confiscation of criminal proceeds, compensation for damages and denial of services and job opportunities through registration on a fraudster database, for example Cifas (n.d).

Table 7: Reduce rewards through formal sanctions

\begin{tabular}{|c|c|c|c|c|c|c|c|c|c|c|}
\hline & & & & & & Overseas & & & UK & \\
\hline & All & ctors & $\begin{array}{l}\text { Private } \\
\text { sector }\end{array}$ & $\begin{array}{l}\text { Public } \\
\text { sector }\end{array}$ & $\begin{array}{c}\text { All } \\
\text { sectors }\end{array}$ & $\begin{array}{l}\text { Private } \\
\text { sector }\end{array}$ & $\begin{array}{l}\text { Public } \\
\text { sector }\end{array}$ & $\begin{array}{c}\text { All } \\
\text { sectors }\end{array}$ & $\begin{array}{l}\text { Private } \\
\text { sector }\end{array}$ & $\begin{array}{l}\text { Public } \\
\text { sector }\end{array}$ \\
\hline Toolbox & Eff & $\% \mathrm{Im}$ & Eff $\%$ Im & Eff $\% \mathrm{Im}$ & Eff $\%$ Im & Eff $\% \mathrm{Im}$ & Eff $\% \mathrm{Im}$ & Eff $\% \mathrm{Im}$ & Eff $\% \mathrm{Im}$ & Eff $\% \mathrm{Im}$ \\
\hline anctions & 5.3 & $38 \%$ & $5.235 \%$ & $5.342 \%$ & $5.235 \%$ & $5.135 \%$ & $5.150 \%$ & $5.439 \%$ & $5.336 \%$ & $5.340 \%$ \\
\hline
\end{tabular}

Overall respondents across all sectors perceive formal sanctions as one of the most effective ways of countering corruption with an average score of 5.3 , yet it only attracts a $38 \%$ implementation level (Table 7). When corrupt employees are detected, $52 \%$ of respondents try to use the criminal prosecution system and $44 \%$ seek compensation through the criminal courts; $40 \%$ seek regulatory sanctions; $30 \%$ litigate through the civil process; and just $24 \%$ register offending employees on corruption databases. This paper does not explore why organisations are ineffective in pursuing formal sanctions, whether it is due, for example, to the difficulties in accessing justice, an inadequate cost benefit calculus, or the desire to protect corporate reputations (Braithwaite and Fisse, 1987; Levi and Sherwin, 1989; Button, Wakefield, Brooks, Lewis and Shepherd, 2015). Reputational concerns is reflected in the fact that only $38 \%$ of participants actively publicise formal sanctions. The tension between seeking proportionate justice and organisations' utilitarian goals is exemplified by one interviewees who believes in the deterrence value of formal sanctions but is deflected because "I don't think the shareholders would say the same thing." The result is that the perceived effectiveness of formal sanctions is undermined by the failure of organisations to pursue them. 


\section{$\underline{\text { Reduce provocations }}$}

Personal counselling and ethical support programmes share a number of instrumental features: they provide direct help to employees in orientating their decision choices, they remind employees of their ethical responsibilities and they reveal individuals' problems which may otherwise remain unshared. Table 8 indicates that the technique is regarded as reasonably effective (4.7), used by most organisations $(80 \%)$ but is less popular overseas.

Table 8: Reduce provocations through employee assistance

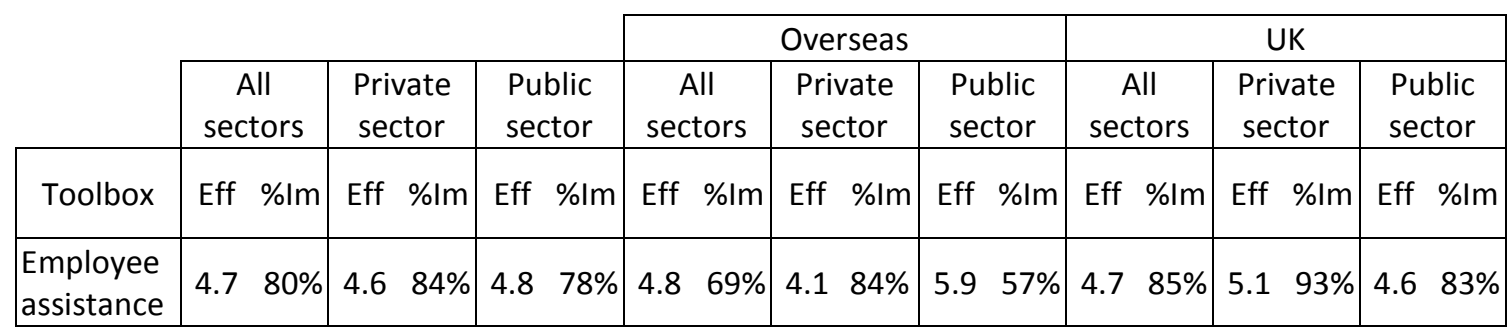

Interview participants were unable to provide any empirical evidence of the effectiveness of assistance programmes. By their very nature they are difficult tools to measure and rely on the commitment of organisations to social values. This perhaps explains why the rate of implementation is so variable, ranging from $57 \%$ in the overseas public sector to $93 \%$ in the UK private sector. A sporting regulator commented that counselling services are used to prevent members from being drawn into a downward spiral caused by personal financial pressures. One participant considered that the techniques fall within the organisation's duty of care towards its staff:

"We do, certainly offer a counselling service and, yeah, I mean, generally I think it's quite a supportive organisation of trying to help people through their problems." (Senior Fraud Manager, public sector)

However others perceived problems with counselling programmes particularly regarding genuine confidentiality and trust:

"I know there were suspicions about ours with how confidential information would be and I think that stops people from using it but that's normal." (Security Manager, private sector)

\section{$\underline{\text { Remove excuses }}$}

The organisational environment ought to be the ideal context for neutralising excuses: organisations can write their own local rules, train employees in their meaning and application, check that people understand them and continually reinforce their relevance. From Table 9, the survey respondents concur. Implementing clear corruption rules is perceived by the respondents as the second most effective technique, behind recruitment screening, with an overall score of 5.4 and is consistently high across all the sectors. An interview participant expressed his enthusiasm for training and subsequent support:

"Then they go on to induction, everybody has to do their induction before they turn up for work and at induction, they get to meet the counter fraud specialists and 
security management specialist and they'll get talks on fraud and corruption .... encouraging systems like whistle blowing etc, and they'll go through interesting cases.....because everybody wants to know from the fraud specialist, you know, 'Tell me about a good case,' and that's how they get interested in it and it's not unusual either to get phone calls from inductees shortly after they get into the workplace saying, 'I'm really not so sure about this system.' We tell them as well, 'Don't worry you phone, we'll have a look and we'll report back to you, if it's safe, you're alright, we'll tell you one way or the other, but we'd rather you told us than not." (Senior Counter Fraud Specialist, public sector)

It is therefore surprising that the overall implementation level is low and highly variable for a simple technique. It appears to be most popular overseas whilst attracting the least enthusiasm in the UK public sector. Although the great majority of organisations set clear corruption rules (93\%), the problem appears to be that a significant portion are less inclined to train employees (79\%), ensure employees commitment to the rules by signing they have understood them (66\%), and subsequently reinforce the rules (67\%). Removing excuses by ensuring clarity of rules is evidently an effective technique, but there is too often a dislocation between the original intent and effective follow through.

Table 9: Remove excuses by setting clear rules

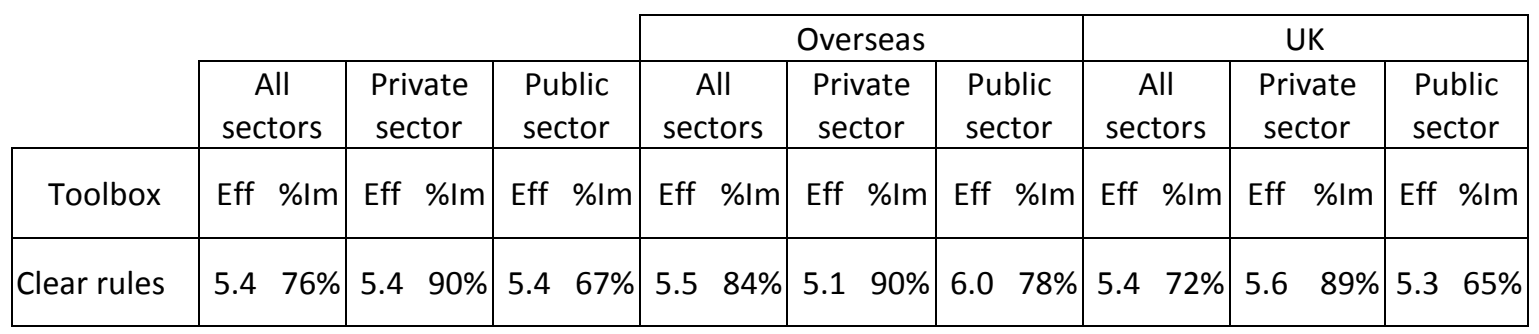

\section{Ethics programme}

The organisation is also an ideal environment for expanding the deontological approach through the development of ethical climates so that employees' potential for engaging in corrupt activities is voluntarily neutralised by their investment in the organisation's normative values (Trevino and Weaver, 2003). The survey probed the perceptions of ethical climate in respect of the organisations' interactions with employees via training and formal communications. Two additional techniques were also included which focus on the organisation rather than the direct impact on potential offenders. They indicate the appetite of organisations for ethical development through reflective learning processes: staff surveys of morale, integrity and attitude to corruption, and using the learning from detected corrupt events to refine strategies.

Table 10: Anti-corruption culture

\begin{tabular}{|c|c|c|c|c|c|c|c|c|c|}
\hline & & & & \multicolumn{3}{|c|}{ Overseas } & \multicolumn{3}{|c|}{ UK } \\
\hline & $\begin{array}{c}\text { All } \\
\text { sectors }\end{array}$ & $\begin{array}{l}\text { Private } \\
\text { sector }\end{array}$ & $\begin{array}{l}\text { Public } \\
\text { sector }\end{array}$ & $\begin{array}{c}\text { All } \\
\text { sectors }\end{array}$ & $\begin{array}{c}\text { Private } \\
\text { sector }\end{array}$ & $\begin{array}{l}\text { Public } \\
\text { sector }\end{array}$ & $\begin{array}{c}\text { All } \\
\text { sectors }\end{array}$ & $\begin{array}{l}\text { Private } \\
\text { sector }\end{array}$ & $\begin{array}{l}\text { Public } \\
\text { sector }\end{array}$ \\
\hline Toolbox & Eff $\% \mathrm{Im}$ & Eff $\% \mathrm{~lm}$ & Eff $\% \mathrm{Im}$ & Eff $\% \mathrm{Im}$ & Eff $\% \mathrm{Im}$ & Eff $\%$ Im & Eff $\% \mathrm{Im}$ & Eff $\%$ Im & Eff $\%$ Im \\
\hline $\begin{array}{l}\text { Learning } \\
\text { from events }\end{array}$ & $5.348 \%$ & $5.650 \%$ & $5.143 \%$ & $5.153 \%$ & $5.150 \%$ & $4.8 \quad 50 \%$ & $5.4 \quad 47 \%$ & $50 \%$ & $5.241 \%$ \\
\hline Ethics tools & $5.154 \%$ & $5.058 \%$ & $5.251 \%$ & $5.258 \%$ & $4.858 \%$ & $5.5 \quad 58 \%$ & $5.152 \%$ & $5.1 \quad 57 \%$ & $5.249 \%$ \\
\hline
\end{tabular}




\begin{tabular}{|l|ll|ll|ll|ll|ll|ll|ll|ll|ll|}
\hline $\begin{array}{l}\text { Employee } \\
\text { surveys }\end{array}$ & 4.0 & $38 \%$ & 4.1 & $44 \%$ & 3.9 & $33 \%$ & 3.8 & $35 \%$ & 3.7 & $44 \%$ & 3.7 & $17 \%$ & 4.0 & $39 \%$ & 4.4 & $43 \%$ & 3.9 & $37 \%$ \\
\hline
\end{tabular}

Referring to Table 10, learning from events (5.3) and ethics tools (5.1) are both highly regarded techniques across all sectors, placed third and sixth in the ranking of effectiveness. The survey is viewed as far less useful, ranked 17th of all the techniques with a score of 4.0. The implementation level for all three techniques is low. The results suggest that, though counter-corruption professionals recognise the value of developing ethical climates, there appears to be a general lack of management support.

\section{Discussion}

The finding that $58 \%$ of respondents rate corruption as a significant problem in their organisations is consistent with the perceptions in the E\&Y $(2014,2015)$ and PWC $(2016)$ surveys that corruption is widespread in the respondents' countries $(51 \%, 68 \%$ and $39 \%)$. That internal fraud is seen as the greatest threat resonates with the PwC (2016) survey which found that most frauds against organisations are perpetrated by employees. The scale of corruption in these surveys may be partly explained by the overall low level of implementation of the prevention techniques: it is below $80 \%$ for all but one of the techniques (Figure 2). The variability in the implementation is also a contributory factor. Analysis of the data reveals gaps between the respondents' views of the effectiveness of the techniques and organisations' support for their deployment. One might expect, at the very least, that the techniques regarded as the most effective would attract management commitment. However, the arrangement of the data in Figure 2 does not show a clear correlation. Furthermore a closer examination of the attributes of each technique does not lead to a reliable, systematic explanation for the lack of correlation.

The techniques with the highest levels of implementation tend to include methods which are necessary for controlling routine organisational activities other than counter-corruption, for example clear rules, supervisory controls, internal and external audits. The relatively low regard for internal audit suggests that schemes are often poorly designed in relation to the detection of corruption or control vulnerabilities. The external audit is clearly an outlier: the regulatory requirements make it the most prevalent but least effective technique. Without reshaping its purpose, external audit can be virtually dismissed as a prevention measure. The weak implementation of formal sanctions can be explained by the difficulties and costs in accessing justice and possibly by reference to reputational concerns (Button, Wakefield, Brooks, Lewis and Shepherd, 2015).

The techniques with the lowest levels of implementation tend to be nonessential to the day-to-day running of organisations: post-employment screening, system and staff integrity tests. They are occasionally employed in support of reactive investigations alongside post-employment screening, credit checks, media and social media searches. A feature common to these techniques and methods is that they imply inherent distrust of employees. One can therefore adduce that management tend to resist tools that are inimical to trust, and potentially stoke resentment, until events dictate their use is necessary. 
Figure 2: Correlating effectiveness and implementation

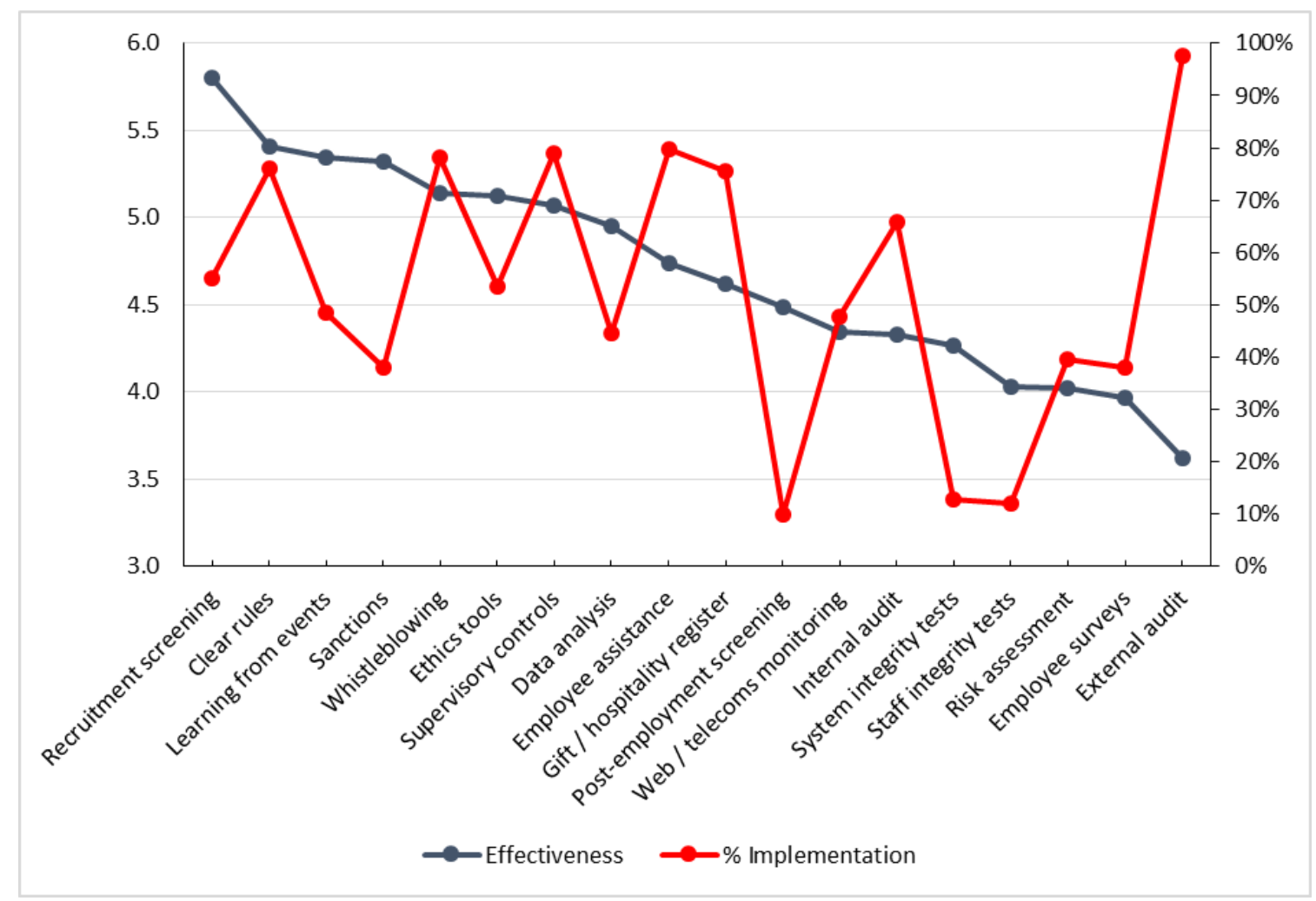

The most perplexing result is the general lack of regard and prevalence of risk assessments. Because the study focused on the risks of corruption associated with employees and their roles, it could be argued that the result also reflects a management resistance to a measure which challenges trust and organisational harmony. Therefore it might be expected that risk assessments of third parties would be commonplace. However the E\&Y (2015) survey found that just $24 \%$ of organisations perform background checks of third parties.

Further research is required to explain these results because risk assessment is fundamental to the corporate mentality (Johnston and Shearing, 2003, p79) and it is an essential component of anticorruption systems (BS 10500:2011). The comment by one interviewee, that he has to force his colleagues into performing risk assessments, is one clue that broad co-operative engagement requires a champion with clout (Braithwaite and Fisse, 1987, p226). A public sector manager without sufficient power expressed similar frustrations:

"I don't think they're really taking it seriously and I think that filters down to staff. I think it's going to take a massive fraud for them to say, 'Maybe we do need to look at this,' you know." (Counter-fraud Manager, public sector)

These observations suggest that the determinant factor in the implementation of counter-corruption techniques is not their effectiveness but whether the anti-corruption function has the support of the organisation's leadership with commensurate power and resources to overcome the inhibitions and reluctance of line managers. The situational corruption prevention framework based on Clarke's (2005) methods provides a mechanism to explain, justify and engage these managers in thinking about corruption and how to reinforce defences. It also offers researchers a system for analysing corruption 
in the organisational context. In doing so, the present study suggests that the presence of features is an inadequate indication of an organisation's commitment to ethical values. Researchers should also consider the additional dimensions of activities, meaningful implementation and effectiveness.

The list of techniques and methods included in the study is not comprehensive because every situation is unique; their purpose is to illustrate the application of the framework. For example, companies ought to include elements relating to customers and public bodies should examine the services they provide to the public. Both sectors need to consider the processes involved in the relationships with third party partners, suppliers and intermediaries. All of these external relationships are susceptible to the fraudulent inflation of contract prices to fund kickbacks. Managers could, for example, consider how to increase the effort, perhaps by having an unconnected colleague directly receive and assess sealed tender bids, or receiving bids into a secure, central e-mail account supervised by the IT department. Risks could be increased by conducting highly visible surprise audits of the tender processes. Rewards could be reduced by including pre-contract tender terms which penalise employees and suppliers for non-compliance. Excuses could be removed by including highlighted warnings in the tender documents. Had the Head of the Royal Household incorporated such arrangements in its procurement processes, perhaps Ronald Harper would not have got away with f100,000 over 5 years (CPS, 2016, August 9).

\section{Conclusions}

This paper first sought to quantify and rank the perceived threat of the most common types of occupational corruption. The greatest threat is occupational fraud, followed by other unspecified corruption and integrity problems, and lastly bribery. Further research is required to understand the nature of the unspecified problems. The situational corruption prevention framework developed is close to Clarke's, but with important differences. Clarke's system places greater emphasis on physical security. The corruption system focuses primarily on bureaucratic systems of vigilance and control. It provides a framework for engaging managers and employees in co-operatively analysing specific situations to design and implement prevention methods. Ethical development programmes undoubtedly have powerful potential but additional work is required to further test and incorporate the endeavours of business ethics scholars into the framework.

While the generalizability of the results presented here are limited, they nevertheless provide an insight into the views of a large group of counter corruption professionals regarding the use of the situational preventative tools. The study provides valuable empirical data for further research and for informing the development of corruption prevention practice. It shows that the general level of implementation of the techniques is low. It also demonstrates that there is no obvious systematic relationship between the perceived effectiveness of the techniques and the level of their implementation.

A particularly surprising result is the weak implementation and poor regard for post-employment screening and the risk assessment of staff roles. The study hypothesises that managers are reluctant to employ these and other tools for prevention purposes for fear that they undermine trust and disrupt organisational harmony. Methods which challenge trust tend to be reserved for investigative purposes, circumstances which indicate a prior breakdown in trust. A final observation is the importance of clout. Counter-corruption champions need executive support and resources to embed techniques and mentor colleagues in order to enhance organisational resilience. Too often executive commitment is absent and further research is required to understand why this is so.

\section{References}


ACFE (2016). Report to the nations on occupational fraud and abuse. Retrieved from: http://www.acfe.com/rttn2016/docs/2016-report-to-the-nations.pdf

Albrecht, C., Sanders, M., Holland, D and Albrecht, C. (2011). The debilitating effects of fraud in organizations. In R. Burke, E. Tomlinson and C. Cooper (Eds.). Crime and corruption in organizations: Why it occurs and what to do about it. Farnham: Gower Publishing.

Benson, M. and Madensen, T. (2007). Situational crime prevention and white-collar crime. In H. Pontell and G. Geis (Eds.), International handbook of white-collar and corporate crime. Dordrecht: Kluwer Academic Plenum Publishers.

Braithwaite, J. (1989). Crime, shame, and reintegration. Cambridge: Cambridge University Press.

Braithwaite, J. and Fisse, B. (1987). Self-regulation and the control of corporate crime. In C. Shearing and P. Stenning (Eds.), Private Policing. Newbury Park: Sage.

Brooks, G., Button, M., \& Frimpong, K. (2009). Policing fraud in the private sector: a survey of the FTSE 100 companies in the UK. International Journal of Police Science \& Management, 11(4), 493504.

Brown, M., Trevino, L. and Harrison, D. (2005). Ethical leadership: a socio learning perspective for construct development and testing. Organisational Behaviour and Human Decision Processes, 97, 117-134.

Brytting, T., Minogue, R. and Morino, V. (2011). The anatomy of fraud and corruption: organizational causes and remedies. Farnham: Gower.

Bullock, K., Clarke, R. and Tilley, N. (Eds.) (2010). Situational prevention of organised crimes. Cullompton: Willan.

Button, M. and Gee, J. (2013). Countering Fraud for Competitive Advantage. Chichester: Wiley.

Button, M., Wakefield, A., Brooks, G., Lewis, C. and Shepherd, D. (2015). Confronting the "fraud bottleneck": private sanctions for fraud and their implications for justice. Journal of Criminological Research, Policy and Practice, 1, 159-174.

CIPFA (2008). Red Book 2: Managing the risk of fraud - actions to counter fraud and corruption. London: CIPFA.

Cifas (n.d.). About Cifas. Available at: https://www.cifas.org.uk/about_us

Clarke, R. (1995). Situational Crime Prevention. Crime and Justice, Vol. 19.

Clarke, R. (1997). Introduction. In R. Clarke (Ed.), Situational crime prevention successful case studies. New York: Harrow and Heston.

Clarke, R. (2005). Seven misconceptions of situational crime prevention. In N. Tilley (Ed.), Handbook of crime prevention and community safety. Cullompton: Willan.

Clarke, R. (2008). Situational crime prevention. In R. Wortley and L. Mazerolle (Eds.), Environmental criminology and crime analysis. Cullompton: Willan.

Clarke, R. and Cornish, D. (1985). Modelling offenders' decisions. In M. Tonry and N. Morris (Eds.), Crime and Justice, 6. Chicago: University of Chicago Press. 
Clarke, R. and Eck, J. (2003). Become a problem-solving crime analyst. London: Jill Dando Institute of Crime Science.

Clarke, R. and Newman, R. (2006). Outsmarting the terrorists. London: Praeger Publishers.

Clinard, B. and Quinney, R. (1973). Criminal behavior systems: a typology (2nd ed.). New York: Holt, Rinehart and Winston.

Coleman, J. (1992). The theory of white-collar crime: from Sutherland to the 1990s. In K. Schlegel and D. Weisburd, White-collar crime reconsidered. Boston: Northeastern University Press.

Committee on Standards in Public Life (2015). Ethical standards for providers of public services guidance. Retrieved from: https://www.gov.uk/government/publications/online-guidance-onethical-standards-for-public-service-providers

Cornish, D. and Clarke, R. (2003). Opportunities, precipitators and criminal decisions: a reply to Wortley's critique of situational crime prevention. Crime Prevention Studies, 16, 41-96.

CPS (2016, August 9). Six found guilty of corruption in relation to Royal Household contracts. Retrieved from:

http://www.cps.gov.uk/news/latest_news/six_found_guilty_of_corruption_in_relation_to_royal_ho usehold_contracts/

Cressey, D. (1953). Other people's money. Glencoe: The Free Press.

Cressey, D. (1986). Why managers commit fraud. Australian and New Zealand Journal of Criminology, 19, 195-209.

Ditton, J. (1977). Part-time crime: an ethnography of fiddling and pilferage. London: MacMillan Press.

Eicher, S. (Ed.) (2012). Corruption in international business: the challenge of cultural and legal diversity. Farnham: Ashgate.

Ernst and Young (2014). Bribery, corruption and fraud in the Middle East: First Middle East bribery, corruption and fraud survey. Retrieved from: http://www.ey.com/Publication/vwLUAssets/EYbribery-corruption-and-fraud-in-the-me/\$FILE/EY-bribery-corruption-and-fraud-in-the-me.pdf

Ernst and Young (2015). Fraud and corruption - the easy option for growth? Europe, Middle East, India and Africa Fraud Survey 2015. Retrieved from:

http://www.ey.com/Publication/vwLUAssets/ey-emeia-fraud-survey/\$FILE/ey-emeia-fraudsurvey.pdf

Ernst and Young (2016). 14th global fraud survey: Corporate misconduct - individual consequences. Retrieved from: http://www.ey.com/Publication/vwLUAssets/ey-global-fraud-survey-2016/\$FILE/eyglobal-fraud-survey-final.pdf

European Commission. (2013). Identifying and reducing corruption in public procurement in the EU. Retrieved from:http://ec.europa.eu/anti_fraud/documents/anti-fraud-policy/research-andstudies/identifying_reducing_corruption_in_public_procurement_en.pdf

Experian and PKF (2016). Annual fraud indicator 2016. Retrieved from:

http://www.port.ac.uk/media/contacts-and-departments/icjs/ccfs/Annual-Fraud-Indicator-2016.pdf 
Financial Conduct Authority (2015). Financial crime: a guide for firms Part 1: A firm's guide to preventing financial crime. Retrieved from:

https://www.handbook.fca.org.uk/handbook/FC/link/PDF.html

Fletcher, C. and Herrmann, D. (2012). The Internationalisation of corruption: Scale, impact and countermeasures. Farnham: Gower.

Gabor, T. (1994). "Everybody does it!" Crime by the public. Toronto: University of Toronto Press.

Gee, J., Button, M. and Cook, I. (2010). The resilience to fraud of UK plc: comparing the private, public and voluntary sectors. London: PKF. Retrieved from:

http://www.pkf.co.uk/web/pkf.nsf/AAE8EAAE86B019ED80257846004E72A7/\$file/UK+Fraud+Resilie nce+Report.pdf

Giles, S. (2012). Managing fraud risk: a practical guide for directors and managers. Chichester: Wiley.

Gill, M. (2005). Learning from Fraudsters. Leicester: Perpetuity Research and Consultancy International.

Gill, M. and Goldstraw-White, J. (2012). Why commit fraud? In A. Doig (Ed.), Fraud: the counter fraud practitioner's handbook. Farnham: Gower.

Goldstraw-White, J. (2011). White collar crime accounts of offending. Basingstoke: Palgrave.

Goolsarran, S. (2006). Corruption: Its nature, causes and effects - suggestions on the way forward. Journal of Government Financial Management, 55(1), 60-64.

Gorta, A. (1998). Minimising corruption: Applying lessons from the crime prevention literature.

Crime, Law \& Social Change 30, 67-87.

Gorta, A. (2006). Corruption risk areas and corruption resistance. In C. Sampford, A. Shacklock, C. Connors and F. Galtung (Eds.), Measuring corruption. London: Routledge.

Graycar, A. and Prenzler, T. (2013). Understanding and preventing corruption. Basingstoke: Palgrave MacMillan.

Graycar, A. and Sidebottom, A. (2012). Corruption and control: a corruption reduction approach. Journal of Financial Crime, 19(4), 384-399.

Graycar, A. and Smith, R. (2011). Research and practice in corruption: an introduction. Handbook of global research and practice in corruption. Cheltenham: Edward Elgar.

Greenberg, J. (1990). Employee theft as a reaction to underpayment inequity: the hidden cost of pay cuts. Journal of Applied Psychology, 75(5), 561-568.

Hafner, M., Taylor, J., Disley, E., Thebes, S., Barberi, M., Stepanek, M. and Levi, M. (2016). The cost of non-Europe in the area of organised crime and corruption - Annex II. Brussels: European Union.

Retrieved from:

http://www.europarl.europa.eu/RegData/etudes/STUD/2016/579319/EPRS_STU\%282016\%2957931

9_EN.pdf

HM Government (2014). UK anti-corruption plan. Retrieved from:

https://www.gov.uk/government/publications/uk-anti-corruption-plan 
Independent Commission Against Corruption (1996). Practical guide to corruption prevention. Retrieved from: http://regulationbodyofknowledge.org/wpcontent/uploads/2013/03/IndependentCommissionAgainstCorruption_Practical_Guide_to.pdf International Chamber of Commerce (2011). ICC rules on combating corruption. Retrieved from: http://www.iccwbo.org/Advocacy-Codes-and-Rules/Document-centre/2011/ICC-Rules-onCombating-Corruption/

Johnston, L. and Shearing, C. (2003). Governing security: explorations in policing and justice. Abingdon: Routledge.

Kohlberg, L. and Hersh, R. (1977). Moral development: a review of the theory. Theory into Practice, XVL(2), 53-59.

Krause, C. and Gibson, W. (2010). Private commercial bribery: the next wave of anti-corruption enforcement? Financial Fraud Law Report, 2(8), 70-718.

Lambsdorff, J. (2007). The institutional economics of corruption and reform: theory, evidence and policy. Cambridge: Cambridge University Press.

Langseth, P. (2006). Measuring corruption. In C. Sampford, A. Shacklock, C. Connors and F. Galtung (Eds.), Measuring Corruption. London: Routledge.

Levi, M. and Sherwin, D. (1989). Fraud '89: the extent of fraud against large companies and executive views on what should be done about it. London: Ernst \& Young.

Loughman, B. and Sibery, R. (2012). Bribery and corruption: navigating the global risks. John Wiley \& Sons: Hoboken.

Mars, G. (1973). Chance, punters and the fiddle: institutionalised pilferage in a hotel dining room. In M. Warner (Ed.), The sociology of the workplace. New York: Halsted Press.

Ministry of Justice (2011). The Bribery Act 2010: guidance. Retrieved from: https://www.gov.uk/government/publications/bribery-act-2010-guidance

Nettler, G. (1974). Embezzlement without problems. British Journal of Criminology, 14, 70-77.

Newman, G. and Clarke, R. (2003). Superhighway robbery. Cullompton: Willan.

OECD (2010). Good practice guidance on internal controls, ethics, and compliance. Retrieved from: https://www.oecd.org/daf/anti-bribery/44884389.pdf

OECD (2014a). OECD foreign bribery report: An analysis of the crime of bribery of foreign public officials. Retrieved from: http://www.oecd.org/corruption/oecd-foreign-bribery-report-

9789264226616-en.htm

OECD (2014b). The rationale for fighting corruption. Retrieved from:

https://www.oecd.org/cleangovbiz/49693613.pdf

Paine, L. (1996). Moral thinking in management: An essential capability. Business Ethics Quarterly, 6, 477-492.

Petry, E., Mujica, A. and Vickery, D. (1998). Sources and consequences of workplace pressure: increasing the risk of unethical and illegal business practice. Business and Society Review, 99, 25-30. 
PwC (2016). Adjusting the lens on economic crime - Preparation brings opportunity back into focus: global economic crime survey 2016. Retrieved from: https://www.pwc.com/gx/en/economic-crimesurvey/pdf/GlobalEconomicCrimeSurvey2016.pdf

Rohlfsen, R. (2012). Recent developments in foreign and domestic criminal commercial bribery laws. University of Chicago Legal Forum, 2012(1), 151-193.

Schnatterly, K. (2003). Increasing firm value through detection and prevention of white-collar crime. Strategic Management Journal, 24(7), 587-614.

Schuchter, A. and Levi, M. (2015). Beyond the fraud triangle: Swiss and Austrian elite fraudsters. Accounting Forum, 39, 176-187.

Schwartz, M. (2011). How to minimize corruption in business organizations: developing and sustaining an ethical corporate culture. In R. Burke, E. Tomlinson and C. Cooper (Eds.), Crime and corruption in organizations: why it occurs and what to do about it. Farnham: Gower Publishing.

Sullivan, J. (2009). The moral compass of companies: business ethics and corporate governance as anti-corruption tools. New York: International Finance Corporation. Retrieved from:

http://www.ifc.org/wps/wcm/connect/3a387c8048a7e613a4bfe76060ad5911/Focus7_AntiCorrupti on.pdf?MOD=AJPERES

Tanzi, V. (1998). Corruption around the world: Causes, consequences, scope, and cures. International Monetary Fund Staff papers, 45(4), 559-594. Retrieved from: https://www.imf.org/external/Pubs/FT/staffp/1998/12-98/tanzi.htm

The Institute of Internal Auditors (2012). International standards for the professional practice of internal auditing (standards). Retrieved from: https://na.theiia.org/standards-

guidance/Public\%20Documents/IPPF\%202013\%20English.pdf

The World Bank (2004). The costs of corruption. Retrieved from:

http://web.worldbank.org/WBSITE/EXTERNAL/NEWS/0,,contentMDK:20190187 menuPK:34457 pa gePK:34370 piPK:34424 theSitePK:4607,00.html

Transparency International (2011). Corruption in the UK: overview and policy recommendations. Retrieved from the TI website: http://www.transparency.org.uk/publications/corruption-in-the-ukoverview-policy-recommendations/

Transparency International (n.d.). How do you define corruption? Retrieved from: https://www.transparency.org/what-is-corruption/\#define

Trevino, L., Butterfield, K. and McCabe, D. (1998). The ethical context in organizations: influences on employee attitudes and behaviours. Business Ethics Quarterly, 8(3), 447-476.

Trevino, L. and Weaver, G. (2003). Managing ethics in business organizations: social scientific perspectives. Stanford: Stanford University Press.

United Nations (2011). Business against corruption: a framework for action. Retrieved from: https://www.unglobalcompact.org/docs/news_events/8.1/bac_fin.pdf

United Nations (2013). A guide for anti-corruption risk assessment. Retrieved from:

https://www.unglobalcompact.org/library/411 
United States Sentencing Commission (2011). Federal sentencing guidelines manual $20118 b 2 \_1$ Remedying harm from criminal conduct, and effective compliance and ethics program. Retrieved from: http://www.ussc.gov/guidelines/2015-guidelines-manual/archive/2011-8b21

US Department of Justice (2008). US DoJ sentencing memorandum. Retrieved from the US Department of Justice website: http://www.justice.gov/opa/documents/siemens-sentencingmemo.pdf

Weaver, G. and Trevino, K. (1999). Compliance and values oriented ethics programs: influences on employees' attitudes and behaviour. Business Ethics Quarterly, 9(2), 315-335.

Wegner, S., Schoberlein, J. and Biermann, S. (2013). Motivating business to counter corruption: a practitioner handbook on anti-corruption incentives and sanctions. Berlin: Humboldt-Viadrina School of Governance. Retrieved from: http://www.governance-platform.org/wpcontent/uploads/2015/01/HVSG_ACIS_PractitionerHandbook_20131121.pdf

World Economic Forum (2011). Clean business is good business. Retrieved from: http://www3.weforum.org/docs/WEF_PACl_BusinessCaseFightingCorruption_2011.pdf Wortley, R. (2001). A classification of techniques for controlling situational precipitators of crime. Security Journal, 14(4), 63-82.

Wortley, R. and Smallbone, S. (Eds.) (2006). Situational prevention of child sexual abuse. Monsey: Criminal Justice Press. 